\section{W.E.UPJOHN \\ INSTITUTE \\ FOR EMPLOYMENT RESEARCH}

\section{Employment Research Newsletter}

$7-1-2010$

\title{
Evaluation of Regional Collaborations for Economic Development: Lessons from the Employment and Training Adminsitration's WIRED Initiative
}

Kevin M. Hollenbeck

W.E. Upjohn Institute for Employment Research, hollenbeck@upjohn.org

Nancy Hewat

Public Policy Associates

Follow this and additional works at: https://research.upjohn.org/empl_research

Part of the Labor Economics Commons

\section{Citation}

Hollenbeck, Kevin M. and Nancy Hewat. 2010. "Evaluation of Regional Collaborations for Economic Development: Lessons from the Employment and Training Administration's WIRED Initiative." Employment Research 17(3): 1-4. https://doi.org/10.17848/1075-8445.17(3)-1 
In this issue ...

Kevin Hollenbeck and Nancy Hewat Evaluation of Regional Collaborations for Economic Development: Lessons from The Employment and Training Administration's WIRED Initiative

William Kern

The Economics of Natural and Unnatural Disasters

New and Award-Winning Books

Vol. 17 , No. 3

Employment Research is published quarterly by the W.E. Upjohn Institute for Employment Research. Issues appear in January, April, July, and October.

The Institute is a nonprofit, independent research organization devoted to finding and promoting solutions to employment-related problems at the international, national, state, and local levels. The Institute is an activity of the W.E. Upjohn Unemployment Trustee Corporation, which was established in 1932 to administer a fund set aside by Dr. W.E. Upjohn, founder of the Upjohn Company, to conduct research on the causes and effects of unemployment and seek measures for the alleviation of the hardships suffered by the unemployed.

W.E. Upjohn Institute for Employment Research $300 \mathrm{~S}$. Westnedge Avenue Kalamazoo, MI 49007-4686 (269) 343-5541

www.upjohn.org

Randall W. Eberts President

Kevin Hollenbeck and Nancy Hewat

\section{Evaluation of Regional Collaborations for Economic Development Lessons from the Employment and Training Administration's WIRED Initiative}

B development initiative launched by the Council on Competitiveness (2006) and sponsored by the Economic Development Administration (EDA), the Employment and Training Administration (ETA) of the U.S. Department of Labor promoted and funded the Workforce Innovation in Regional Economic Development (WIRED) Initiative. In late 2005, ETA released a solicitation for grant applications (SGA) for WIRED that stated, "The ultimate goal of the WIRED Initiative is to expand employment and advancement opportunities for American workers and catalyze the creation of high-skill and high-wage opportunities."

As a result of this solicitation, 13 regions were awarded grants in 2006 totaling \$15 million each (\$5 million per year for three years). They became known as the Generation I WIRED regions. Another 13 regions were awarded planning grants of $\$ 100,000$ and were designated as virtual sites. In October 2006, ETA awarded a contract to Berkeley Policy Associates and its partner, the University of California, San Diego, to evaluate the Generation I regions. In January 2007, the virtual regions were designated as Generation
II WIRED grantees and were awarded a total of \$5 million in funding over three years. ${ }^{1}$ In February 2007, a second SGA was released for Generation III regions.' Again, 13 regions were selected, and as with the Generation II regions, these sites were granted a total of $\$ 5$ million over three years. In late fall 2007, ETA awarded a contract to Public Policy Associates of Lansing, Michigan, and its partner, the Upjohn Institute, to evaluate Generation II and III of WIRED and do a cross-generational (Generations I, II, and III) assessment of the WIRED strategy.

The evaluation contracts are ongoing, and the two evaluation teams have each published two interim reports of the findings (Almandsmith et al. 2008, 2009; Hewat et al. 2009; Hollenbeck et al. forthcoming). The purpose of this article is to summarize key findings to date from these evaluations. It proceeds first by presenting the notion of a regional collaborative and comparing and contrasting that type of entity to a local workforce board and a workforce intermediary. The article then reviews some of the findings from the evaluators' interim reports and draws some conclusions about the extent to which WIRED has resulted in or contributed to a transformation of the workforce system. 


\section{Regional Collaborations}

For purposes of this article, we will refer to the WIRED regions as regional collaborations. ${ }^{3}$ We posit that such collaborations differ in fundamental ways from local workforce investment boards (LWIBs) and from workforce intermediaries. Table 1 displays several characteristics of each of these types of entities.

In general, the regional collaborations are broader in concept and operation than either LWIBs or workforce intermediaries. Although as mentioned below, ETA attempted to refocus some of the efforts of the WIRED regions on disadvantaged workers, but for the most part, the regions see the entire labor force and employers as their target populations. Geographically, regional collaborations tend to involve multiple labor markets and may cross state boundaries. The strategies employed by regional collaborations often include building linkages with the educational system, with the goal of integrating and strengthening science, technology, engineering, and math (STEM) instruction, which is seen as a key element in the development of a competitive workforce.

\section{Interim Findings from the Evaluations}

The Almandsmith et al. (2008) report, subtitled 2007 Interim Evaluation Report, is mainly based on site visits to the Generation I regions early in their implementation. Most of the analyses in that report focus on the progress that sites have made in launching their initiatives. The analyses point out the wide variation in contexts across the sites in terms of regional economic structure, political and jurisdictional boundaries, prior collaborative efforts, and other factors. The report presents a typology of early implementation in which three regions were identified as being accelerated by WIRED, seven regions were jumpstarted by WIRED, and three regions were launched by WIRED.

The report notes that the most prevalent type of organization administering the WIRED initiatives were economic

Table 1 Comparison of Regional Collaborations, Local Workforce Investment Boards, and Workforce Intermediaries

\begin{tabular}{|c|c|c|c|}
\hline Characteristic & $\begin{array}{l}\text { Regional } \\
\text { collaborations (e.g., } \\
\text { WIRED regions) }\end{array}$ & $\begin{array}{l}\text { Local workforce } \\
\text { investment boards }\end{array}$ & $\begin{array}{l}\text { Workforce } \\
\text { intermediaries }\end{array}$ \\
\hline $\begin{array}{l}\text { Client population } \\
\text { served (supply side) }\end{array}$ & Total labor force & $\begin{array}{l}\text { Primarily } \\
\text { disadvantaged/ } \\
\text { dislocated }\end{array}$ & $\begin{array}{l}\text { Primarily } \\
\text { disadvantaged }^{\text {a }}\end{array}$ \\
\hline Sectoral basis & $\begin{array}{l}\text { Sectors, broadly } \\
\text { defined }\end{array}$ & Not sectoral based & $\begin{array}{l}\text { Usually sectoral } \\
\text { based }\end{array}$ \\
\hline $\begin{array}{l}\text { Employer engagement } \\
\text { (demand side) }\end{array}$ & $\begin{array}{l}\text { Employer/industry } \\
\text { representation }\end{array}$ & $\begin{array}{l}\text { Individual employer } \\
\text { focused }\end{array}$ & Employer-driven \\
\hline Regulation & Less regulated & Regulated & Virtually none \\
\hline Human capital strategy & $\begin{array}{l}\text { Worker training, } \\
\text { entrepreneurship, } \\
\text { K-20 pipeline, esp. } \\
\text { STEM }\end{array}$ & Worker training & $\begin{array}{l}\text { Worker training; } \\
\text { some educational } \\
\text { focus }\end{array}$ \\
\hline Geography & $\begin{array}{l}\text { Usually, multiple } \\
\text { labor markets }\end{array}$ & Single labor market & Single labor market \\
\hline Multistate & May cross state lines & No & Not typical \\
\hline Staffing & Staffed lightly & Staffed substantially & Staffed lightly \\
\hline Leveraged resources & $\begin{array}{l}\text { Yes (public and } \\
\text { private) }\end{array}$ & $\begin{array}{l}\text { Public resources, but } \\
\text { typically multiple } \\
\text { funding streams }\end{array}$ & By definition \\
\hline
\end{tabular}

aSee Marano and Tarr (2004, Table 4.1).

development entities. Furthermore, it indicates that (single) steering committees were the primary governance structure, and that early implementation progress was considerably impeded by two factors: 1) recruiting staff and turnover, and 2) having to redirect funds and priorities after receiving ETA clarifications about allowable use of funds.

Hewat et al. (2009) also document the early implementation of WIRED initiatives in the Generation II and III regions. Their report indicates that many of the same phenomena pointed out in the interim report for the Generation I regions held true for the Generation II and III regions as well. The report finds that the pre-WIRED economic, political, and cultural contexts of the regions shaped each region's initiatives and pace of implementation. It also documents the regions' frustration with what officials considered to be inconsistent and changing messages from ETA, as well as glacial approval processes for implementation plans.

A slight difference between the first interim reports for Generation I and for Generations II and III is that the latter acknowledges that the regions created formal governance structures but portrays the leadership of each region as comprised of three rings rather than emanating from a single steering committee. The report states: “. . . core leaders serve as the intellectual center and energy for the initiative. A second ring of leaders are actively engaged but do not have final authority for committing resources. A third ring includes individuals who lead particular aspects of the implementation plan, such as a sectorspecific project."

Much of the data for the Hewat et al. (2009) report come from site visits. Many of the individuals who were interviewed offered opinions about the value of taking a regional approach, noting that the most important accomplishment that occurred in their region was the formation and convening of partnerships that had all of the key players at the table. Many of the regions had preexisting collaborative partnerships but had been missing stakeholders from the economic or talent development systems. That may help 
explain why, even in the early stages of the initiatives, individuals in many of the regions had a sense that regionalism had started to take hold.

An interesting finding in Hewat et al. (2009) is that the evaluation team did not identify any significant differences in governance structures or activities between the Generation II and Generation III regions, save a significantly larger amount of leveraged resources in the former. This may have occurred because several of the Generation II regions had to curtail their original plans due to the significant decrease in grant funds, but they remained committed to their overall goals as stated in the Generation I proposal and found other funding sources to fill the gaps. In contrast, the funding expectations for Generation III regions were clear from the start.

Almandsmith et al. (2009) offer another snapshot of the Generation I regions based on a second site visit toward the end of the grant period. A significant event that affected all of the regions was the economic recession that began in December 2007. The downturn significantly reduced employment opportunities for emerging workers, and also reduced public, private, and philanthropic support for the local and regional initiatives. The report notes that little change had occurred in the regions in terms of governance and management structures, although two regions expanded their targeted industrial sectors because of the economy's negative impact on their primary sectoral targets. Also, because of a change in emphasis at ETA, a few other regions turned some attention to disadvantaged worker populations. $^{4}$

As regions progressed into the operational phase, there was a natural shift in emphasis from planning and development to worker training and other education-related activities. Many regions offered activities to promote entrepreneurship, and many invested resources in the talent development pipeline. Many also supported some sort of STEM activity.

Almandsmith et al. (2009) suggest that two significant regulatory events occurred in 2008 that affected all of the regions. First, ETA undertook fiscal monitoring reviews that resulted in a significant number of disallowed costs, primarily because the Generation I regional leaders were not from the workforce system and thus were not familiar with regulations; however, there were some differences in interpretation among ETA monitors assigned to the regions, which was a contributing factor. Second, ETA developed and disseminated an accountability framework that included quarterly reporting of the common measures. According to stakeholders in numerous regions, these events shifted the focus of the regional initiatives toward accountability and cost documentation and away from the emphasis on collaboration, innovation, and transformation that had rallied regional stakeholders around WIRED.

\section{The pre-WIRED economic, political, and cultural contexts of the regions shaped each region's initiatives and pace of implementation.}

The second interim report for the evaluation of the Generation II and III regions (Hollenbeck et al. forthcoming) is based almost exclusively on selfreported data from a survey of regions' partners, which was conducted before this evaluation team's second round of site visits and independent of any fallout from financial audits and accountability frameworks. The survey results indicated that all of the regions had representation in their partnerships from all stakeholder groups. However, more partners came from the educational sector than any other organization type.

The survey queried respondents about the context for the region's initiative in terms of collaboration and trust. Asked to recall the context of the region in 2006, almost 100 percent of respondents indicated that when the WIRED grants became available, the political and social climate in their region was ripe for starting a transformative collaboration. Considerably smaller percentages of respondents, but still over half, characterized the historical context of collaboration in their region as one of working together or trust.

The survey presented respondents with a scale to describe the stage of collaboration currently in existence in their region. This scale, in ascending order of maturity, ranged from coexistence to communication to coordination to cooperation to collaboration. The survey respondents on average rated themselves in the range between coordination and cooperation. Finally, more than 90 percent of the partners perceived the outcomes at that point in time as quite beneficial for their organization and its "ability to improve the job skills of our regional workforce."

In summary, the interim reports of the WIRED evaluations paint a picture of engaged and effective regional partnerships that are facilitating training (including entrepreneurial activities) and educational pipeline investment, especially in STEM areas. It is likely that significant benefits are accruing to the individuals and organizations involved in the regional initiatives and engaged in the regional and national networks that were formed to support learning and sharing of strategies, innovative practices, and lessons learned.

In our opinion, some significant issues that have not been addressed in the interim reports include the costs in terms of resources and time that have gone into the partnerships. Without cost information, it is impossible to gauge benefits against costs or estimate roughly a return on the federal investment. Another issue is the macroeconomic or general equilibrium impacts of the WIRED investments. If benefits are accruing within WIRED regions, does that mean that other regions of the country have less economic growth, or is there complementarity such that positive economic growth in WIRED regions stimulates non-WIRED regional growth?

\section{Transformation?}

The 2007 SGA for the Generation III regions indicated that "a key focus for WIRED is to implement strategies that will result in their workforce investment 
system becoming a key component of their region's economic development strategy.” The solicitation goes on to say, "In this vision, elements of a transformed (emphasis added) workforce system are:

- The workforce system operates as a talent development system; it is no longer defined as a job training system.

- Workforce investment system formula funds are transformed, providing tuition assistance for postsecondary education for lifelong learning opportunities aligned with the region's talent development strategy.

- The workforce investment system no longer operates as an array of siloed programs and services.

- The workforce investment boards are structured and operate on a regional basis.

- Economic and workforce development regions are aligned, and these regions adopt common and innovative policies that support talent development and the regional economy.

- The workforce investment system is agile enough to serve the innovation economy.

- The workforce investment system actively collaborates with economic development, business, and education partners to gather and analyze a wide array of current and real time workforce and economic data.

The interim reports note that a number of significant changes have occurred or are occurring in the 39 regions. But, as Almandsmith et al. (2009) state, “The changes observed do not (yet) rise to the level of 'transformation' of the full workforce system.” However, site visitors have met with key partners from many regions who have articulated a vision of change that may take more than three years to fully realize.

\section{Notes}

1. These regions applied for funding under the first SGA and therefore had proposed scopes of work under the expectation of receiving \$15 million. During the planning period and early implementation phase, the scopes were necessarily reduced, but the regions leveraged considerable funding.

2. Unlike the other two generations, the Generation III applicants were required to have the lead individual or a co-lead individual from the public workforce system.

3. The geographic areas identified through the EDA initiative titled Regional Innovation Clusters seem to essentially be the same as what we refer to as regional collaborations. See EDA (2010).

4. ETA made additional funds available to regions that were ready to put a special emphasis on these job seekers.

5 . All of the survey data need to be analyzed with caution due to the potential for response biases and to the vagaries of selfreported data.

\section{References}

Almandsmith, Sherry, Mary Walshok, Kay Magill, Linda Toms Barker, Pamela Surko, Mary Vencill, Tommy Smith, Hannah Betesh, and June Chocheles. 2008. Early Implementation of Generation I of the Workforce Innovation in Regional Economic Development (WIRED) Initiative: 2007 Interim Evaluation Report. Report submitted to U.S. Department of Labor, ETA/OGCM, Washington, DC, May 20.

Almandsmith, Sherry, Mary Walshok, Kay Magill, Linda Toms Barker, Pamela Surko, Mary Vencill, Tommy Smith, Hannah Betesh, David Drury, Tricia Cambron, Kristina Lara, and Thomas Goldring. 2009. The Power of Partnership: American Regions Collaborating for Economic Competitiveness: 2009 Generation I WIRED Interim Evaluation Report. Report submitted to U.S. Department of Labor, ETA/OGCM, Washington, DC, November 9.

Council on Competitiveness. 2006. Regional Innovation, National Prosperity. Summary Report of the Regional Competitiveness Initiative \& Proceedings of the 2005 National Summit on Regional Innovation, Council on Competitiveness, Washington, DC.

Economic Development Administration (EDA). 2010. “Regional Innovation
Clusters Initiative Overview.” Powerpoint presentation. Washington, DC: U.S. Department of Commerce.

Hewat, Nancy, Kevin Hollenbeck, Nicholas Armit, Colleen Graber, Jeff Kaplow, David McConnell, Nancy McCrohan, Jeff Padden, Lawrence Rosen, Nathalie Winans, Scott Southard, George Erickcek, and Brad Watts. 2009. Nurturing America's Growth in the Global Marketplace through Talent Development: An Interim Report on the Evaluation of Generations II and III of WIRED. Report submitted to U.S. Department of Labor, Washington, DC, November 23.

Hollenbeck, Kevin, Nancy Hewat, Jeff Kaplow, Monica Long, Nancy McCrohan, Jeffrey Padden, Lawrence Rosen, Scott Southard, George Erickcek, Brad Watts, and Brain Pittelko. Forthcoming. Transforming America's Talent and Economic Development through Regional Collaboration: The Second Interim Report on the Evaluation of Generations II and III of WIRED.

Report submitted to U.S. Department of Labor.

Marano, Cindy, and Kim Tarr. 2004. "The Workforce Intermediary: Profiling the Field of Practice and Its Challenges.” In Workforce Intermediaries for the TwentyFirst Century, Robert P. Giloth, ed. Philadelphia: Temple University Press, pp. 93-123.

Kevin Hollenbeck is vice president and senior economist with the W.E. Upjohn Institute for Employment Research and principal investigator for the ETA-sponsored evaluation of the Generation II and III WIRED Regions.

Nancy Hewat leads the Education, Workforce, and Economic Development Group and serves as a senior project manager at Public Policy Associates, Inc. of Lansing, Michigan, and is the project director for the abovementioned evaluation.

Disclaimer: This article was prepared from information collected under contract to the U.S. Department of Labor, Employment and Training Administration, Office of Policy Development and Research. The contents of this article do not necessarily reflect the views or policies of the Department of Labor; nor does mention of trade names, commercial products, or organizations imply endorsement of same by the U.S. Government. 